Original paper UDC 165(292.6)(045)

doi: $10.21464 / \mathrm{sp} 33104$

Received: May 11,2018

\begin{abstract}
Wilfred Lajul
Makerere University, College of Humanities and Social Sciences, School of Liberal and Performing Arts, P.O. Box 7062, UG-Kampala wodangom.lajul@gmail.com
\end{abstract}

\title{
Reconstructing African Fractured Epistemologies for African Development
}

\begin{abstract}
Africa is a continent with plenty of natural resources, but economically poor. To translate natural resources into profitable wealth that improves the quality of life and wellbeing of the people requires knowledge. Though one cannot deny that Africa, well before coming into contact with the Western world, had its indigenous knowledge system(s), one wonders what must have gone wrong. The crux of the matter seems to lie in the broken legacies of her indigenous knowledge system(s). This is because, while today's world is moving away from resource-based development to knowledge-based development, Africa, with its fractured epistemologies, has only been relying on its abundant natural resources, which are unfortunately being badly managed due to its poor knowledge base. To move from resourcebased development to knowledge-based development, Africa needs to redeem its knowledge $\operatorname{system}(s)$ from the broken pieces. This paper hypothesises that this can only be done through African epistemological reconstruction. Therefore, this paper is investigating the nature of African fractured epistemologies to understand what went wrong and how to put right the wrong that has been done to rejuvenate African knowledge-based development.
\end{abstract}

\section{Keywords}

Africa, fractured epistemology, reconstruction, development, nature

\section{Introduction}

The central discourse in this paper is to identify African epistemologies and discover whether or how it has been fractured by its contact with Western epistemology. I will discuss the place of knowledge in African development, which is to promote the quality of human life and economic situation in Africa. Secondly, I intend to show what constitutes this fracture, if anything, and suggest how such fractured African epistemologies could be reconstructed and used to promote qualitative human and economic development in Africa.

Different people have a different diagnosis of the problem of African development. Some of these development problems can be centred on two issues. The first is the fact that the knowledge base of African development has been tampered with, meaning that what Africa is trying to do to promote the quality of life of her people cannot be achieved unless it is premised by home-grown knowledge. This, in turn, cannot take place unless the fractured African epistemologies are reconstructed. The second issue is that Africa has for a long time been depending on its rich natural resources, yet the world's economic system has shifted from resource-based development to knowledge-based de- 
velopment. This knowledge base, in the case of Africa, as stated above, has been fractured by the African encounter with colonialism. In discussing the possibility of reconstructing African fractured epistemologies for African development, the hypothesis is that African epistemologies exist and that these epistemologies have been fractured. Besides this fact, I am saying that these fractured epistemologies can be reconstructed and it can be used as a basis for African development.

In saying this, I am aware of the concern of authors like Grosfoguel, who thinks that we should avoid using single epistemic position and universalising it to be the basis of critiquing the colonial epistemic legacy. Grosfoguel calls this universalising attempts epistemic fundamentalism. He writes:

"What all fundamentalisms share (including the Eurocentric one) is the premise that there is only one sole epistemic tradition from which to achieve Truth and Universality. However, my main points here are three: (1) that a decolonial epistemic perspective requires a broader canon of thought than simply the Western canon [...]; (2) that a truly universal decolonial perspective cannot be based on an abstract universal (one that raises itself as a universal global design), but would have to be the result of the critical dialogue between diverse critical epistemic/ethical/ political projects towards a pluriversal as oppose to a universal world; (3) that decolonization of knowledge would require to take seriously the epistemic perspective/cosmologies/insights of critical thinkers from the Global South."1

Meaning, in our attempt to criticise and reconstruct broken African epistemologies, we should avoid abstract particular views that raise themselves to universal designs by taking into consideration boarder and balanced epistemic perspectives of critical thinkers. Secondly, this requires some critical dialogue between diverse critical epistemic systems and traditions. Thirdly, the epistemic perspectives of the Global South have to be taken into consideration.

In this paper, however, the focus is not on criticising Western epistemology, though this may not be avoided, but in understanding the point at which African epistemological systems got fractured or halted and how Africans can pick up from there to build the knowledge base for their developments. In fact, different authors are seriously divided on the view that African epistemology exists. On the one hand, the protagonists, like Léopold S. Senghor, Anyanwu and Innocent Oyenwuenyi believe that African epistemology exists. On the other hand, the antagonists like Kwame A. Appiah, Peter O. Bodunrin, and Henry O. Oruka think it does not exist. ${ }^{2}$ In this paper, my view is that African epistemology exists, as we shall later define and explain. This is supported by authors like Emeagwali and Shiza ${ }^{3}$ who call it "African indigenous knowledge system". Emeagwali and Shiza even went far enough to discuss African indigenous scientific knowledge in this epistemology.

The questions that remain and which this paper is to deal with are the following: if African epistemology exists, then what is its nature? Has this African epistemology been tampered with, and if so - how? Can such fractured epistemology be reconstructed, if so - how? Lastly, how can the reconstructed African epistemology be used for African development? In answering these questions, after giving some conceptual clarifications, I will investigate the existence of African epistemologies. Secondly, I will try to find out how these epistemologies have been fractured. Thirdly, we discuss the possibility of reconstructing these fractured epistemologies. And lastly, it is to suggest ways of using the reconstructed African epistemologies for the improvement of African quality of life, both humanly and economically.

The method that will be employed in this work is basically analytical and expository; firstly, I am exposing the views of various authors and critically analysing them to tease out my views in the context of this discussion. 


\section{The Concept of Development and Knowledge}

To proceed with our discussions, it may be necessary to clarify the two key concepts, development and knowledge.

\section{Concept of development}

Amartya Sen presents development as capability expansion. ${ }^{4}$ In another text, he writes the following:

"Development can be seen (...) as a process of expanding the real freedoms that people enjoy. (...) Human beings are the agents, beneficiaries and adjudicators of progress, but they also happen to be-directly or indirectly-the primary means of all production. (...) The problem might have been of no great practical interest if the achievement of economic prosperity were tightly linked-in something like a one-to-one correspondence-with that of enriching the lives of the people. If that were the case, then the pursuit of economic prosperity as an end in itself, while wrong in principle, might have been, in effect, indistinguishable from pursuing it only as a means to the end of enriching human lives." 5

From the above, I can see that Sen is saying, because the end of economic progress can never be one-to-one with enriching lives of humans, the problem is in harmonising the achievement of economic progress by pursuing prosperity as an end in itself, and the enrichment of human lives as the primary end of human development. Unfortunately, these two ends do not easily synchronise. In my view, this problem leads to two tendencies in trying to understand the concept of development. On the one hand, the understanding is that development is equivalent to economic progress, which is the pursuance of economic prosperity as an end in itself, and humans are just means in the production of such prosperity. On the other hand, is to look at development as the enrichment of human lives, where human beings are the agents, beneficiaries and adjudicators of progress. Amartya Sen sees in this second option, the Kantian principle that humans are ends in themselves and never means to anything else. He confirms this in his own words:

"Immanuel Kant argues for the necessity of seeing human beings as ends in themselves, rather than as means to other ends: 'So act as to treat humanity, whether in thine own person or in that of any other, in every case as an end withal, never as means only'."6

1

Ramón Grosfoguel, “The Epistemic Decolonial Turn: Beyond Political-Economy Paradigms", Cultural Studies 21 (2007) 2-3, pp. 211-233, p. 212, doi: https://doi.org/10.1080/ 09502380601162514.

2

Felix Ayemere Airoboman, Anthony Afe Asekhauno, "Is there an 'African' Epistemology?" Journal of Research in National Development 10 (2012) 3, pp. 13-18.

3

Gloria Emeagwali, Edward Shizha, "Interconnecting History, African Indigenous Knowledge Systems and Science", in: Gloria Emeagwali, Edward Shizha (eds.), African Indigenous Knowledge and the Sciences. Journeys into the Past and Present, Sense publishers, Rotterdam, Boston, Taipei 2016, pp. 3-11.
4

Amartya Sen, 'Development as Capability Expansion', Journal of Development Planning 19 (1989), pp. 41-58.

5

Amartya Sen, Development as Freedom, Anchor Books, New York 1999, p. 3. 6

Ibid., citing Kant from: Immanuel Kant, Fundamental Principles of the Metaphysics of Morals, in: Immanuel Kant, Kant's Critique of Practical Reason and Other Works on the Theory of Ethics, Thomas Kingsmill Abbot (ed. \& trans.), Longmans, London 1909, p. 47 . 
This has led to the two concepts of development, one as economic development and the other as human development. ${ }^{7}$ My view is that true development is both economic progress and human enrichment, which is people-centred. Reason being, centring development on economic progress alone ignores the key ingredients of human development, yet human development cannot occur without some economic progress. True development is then the promotion of human capacity for qualitative change; it is the ability to protect the environment, and expand the capacity of humans to embrace and promote economic progress by human knowledge.

Wolfgang Sachs, on the other hand, has presented another interesting and important aspect of development. Without delving into the depth of the discussion at this point, Sachs helps us to see the link between development and the power of knowledge. ${ }^{8}$ In this chapter, I am interested in pursuing the implications of this link between development and knowledge.

Reflecting further, I notice that, while Africa is pursuing its development agenda, by attempting to enlarge the capabilities and freedoms of her people amidst apparent plenitude of resources, one wonders why Africa remains so poor. Africa seems to be a paradoxical continent with plenty of economic resources, yet it is the poorest of all the other continents in the world. In the language of David Attah, quoted by Segun Gbadegesin:

"Africa is a paradox which typifies poverty in the midst of plenty. In terms of developmental potential and natural resources, Africa is about the richest continent in the world and yet in real terms the poorest and the most underdeveloped."

The missing link, in my view, seems to be an absence of the power of knowledge, to propel African development. But this concept of knowledge will also need to be clarified.

\section{Concept of Knowledge}

The discussion on the theory of knowledge in philosophy is referred to as epistemology. Epistemology, which is a branch of philosophy, is defined by Ndubisi as

"... the study of the nature of human knowledge, its origin, its scope, its limits, its justification, its reliability or otherwise, its certainty or otherwise." 10

However, he defines African epistemology as

"... a critical reflection on the African and the African world." 11

Anyanwu adds that

“... the idea of an African epistemology as understood by those who propose it is taken as a way the African conceptualises, interprets and apprehends reality within the context of African cultural or collective experience."12

However, there are two schools of thought with regard to this subject. There are those who maintain that African epistemology does not exist, the Universalists; and those who say that it does exist, the ontologists and particularists, as we shall later discuss. In this paper, my view is that the Universalists objections to the existence of African epistemology is based on the false claim that philosophy can only be done in one way. Indirectly, it is a denial of the existence of African philosophy, a debate that has long been overcome. Even earlier staunch antagonists of African philosophy, like Paulin J. Hountondji, have "cooled down". The many volumes on the discourse of African episte- 
mologies are yet another indication that the problem of the existence of African epistemology is difficult to sweep under the carpet.

I believe that both ontological and particularistic views on African epistemologies are correct since they are not contradictory to each other. Onyewuenyi, an African philosopher from Nigeria and defender of African epistemology, argues that African theory of knowledge follows closely upon ontology. ${ }^{13}$ What African philosophers, particularly K. C. Anyanwu, I. C. Onyewuenyi and others based their argument for a distinctive or unique African epistemology is the proposition that each race is endowed with a distinctive nature and embodies in its civilisation a particular spirit. ${ }^{14}$

That means, we shall understand African epistemologies as ways of knowing that flow from African ontology, which is the symbiotic harmonious relationship within an individual, between an individual and society, and between an individual and nature and the spiritual world of their ancestors and their gods. Because each society has a unique understanding of this ontology, there is deemed to be different ways of understanding these realities and using such understanding in deriving the knowledge society needs for her development.

To conclude this section, I would like to bring in Ramose's view about the internal and external aspects of truth. Ramose states that truth is constituted of two aspects, the internal and the external. The internal aspects mean:

"Knowing oneself in terms of one's identity and ethical disposition (...). It means interacting with others by remaining true to the acquired knowledge of oneself." 15

The external aspect of truth:

“... is an ever-changing human construction of the meaning of life at a given time and place (Bohm 1994:141). This means that human beings do not 'construct', for example, a stone or a river that simply exists whether or not they like it. Human beings do not 'construct' what is generally known as 'objective' reality. Their interaction with this reality is the matrix from which truth, as a statement on the meaning of life, is constructed. This is the 'external' aspect of truth. The internal and external aspects of truth constitute and complement each other."16

See Albert Titus Dalfovo, "Development in Sub-Saharan Africa: The State and the People", in: E. Mawala et al (eds.), Social Reconstruction in Africa. Uganda Philosophical Studies, II, The Council for Research in Values and Philosophy, Washington D. C. 1999, pp. 11-26; Human Development Report 1998, Oxford University Press, New York, Oxford 1998.

8

Cf. Wolfgang Sachs, The Development Dictionary: A Guide to Knowledge as Power, Zed Book, New York 2010.

Segun Gbadegesin, African Philosophy: Traditional Yoruba Philosophy and Contemporary African Realities, Peter Lang, New York (NY) 1991, p. 138

10

Ejikemeuwa J. O. Ndubisi, "Nature and Function of Logic in African Epistemology", JOSR Journal of Humanities and Social Sciences 19 (2014) 7, pp. 32-36, doi: https://doi. org/10.9790/0837-191153236.
11

Ibid., p. 33

12

K. C. Anyanwu, The African experience in the American market place a scaring indictment of western scholars and their distortion of African culture, Exposition Press, New York 1983, p. 60.

13

Innocent Onyewuenyi, "Is there an African philosophy?", Journal of African Studies 3 (1976) 4, pp. 513-528, p. 525.

14

Abiola Irele, The African experience in literature and ideology, Heinemann, London 1981, p.70.

15

Mogobe Ramose, "Dying a hundred deaths: Socrates on truth and justice", in Phronimon 15 (2014) 1, pp. 67-80, p. 68, doi: https://doi. org/10.25159/2413-3086/2213.

16

Ibid. 
My view is that what Ramose is saying, to a great extent has been challenged or even superseded by Western epistemology as we shall later see in Kant's theory of knowledge. While it is true that truth may have these two aspects, internal and external, this way of approaching truth has been superseded by the Kantian Copernican Revolution theory. This theory of knowledge denies Ramose's objective world, the "objective" reality and claims that it cannot be constructed. According to Kantian Copernican revolution, which has been substantially adopted by modern Western epistemology, humans have the rational ability to manipulate the laws of nature embedded in the objective world and can subject the objective world to genetic alteration and production of new realities that did not exist in the natural world.

This has completely changed human construction of the meaning of life. The distinction I am trying to make is how this new epistemic knowledge system has revolutionised modern industries and their products, by which humans are to find their meanings in life. Africa has remained, in line with Ramose, relying on the deep respect of the objective reality as it is, thinking the objective world cannot be altered. The novelty of the discussions in this paper is to find out if African epistemologies are to be reconstructed, and if they are, then it cannot be done without such awareness. Definitely, Ramose is not aware of this new dynamics, as we shall later discuss in details.

\section{The Fractured Nature of African Epistemology}

\section{Writing about African epistemology in the South African and African political} context, Swanson observes that critics think

“... African ways of knowing tend to be enacted and conceptualised as circular, organic and collectivist, rather than linear, unitised, materialistic and individualistic, as is attributed to Western perspectives."17

Besides, traditional African thought in its various forms is said to

“... seek interpretation, expression, understanding, and moral and social harmony, rather than being preoccupied with verification, rationalism, prediction and control, as reified through Western Scientific norms." 18

Implying, that the nature of African epistemology is circular, organic, collectivist, interpretative, expressive, and apologetic, since it is seeking understanding, moral and social harmony; while Western epistemology is linear, unitised, individualistic, verifiable, rational, predictive and preoccupied with evidential control. However, these criticisms are not correct. For example, contrary to the above criticism, there are African thinkers who have resisted this mudslinging by espousing a more communalist or communitarian philosophy and a way of knowing appropriately in alignment with African worldviews and ways of being. ${ }^{19}$ For instance, Ibuot criticizes the way of distinguishing African from Western epistemologies by rationality, individuality and criticality by saying that the principles of rationality defined by logic are not sufficient to understand human knowledge comprehensively since humans are not robots. He argues that

“... man cannot know without the involvement of his emotions, faith/belief, imagination, etc., that the only place you can find a knowledge that does not involve human emotions is artificial intelligence like computers and robots." 20

Thus, there is nothing wrong if African epistemology is also expressive. Besides, Kwame Gyekye criticises the view that communal philosophy is bereft 
of individuality and criticality. This is because when a particular idea has filtered through to us from the diffuse and indistinct unwritten traditions; it does not mean that such an idea was produced collectively. ${ }^{21}$ Equally, the African body of knowledge could not have been produced collectively, since ideas can only be produced by individuals and may be preserved collectively. What is important at this point, without delving deeper into discussions, is to note that

“... within such a collectivist philosophy, the affective, relational and moral philosophical tenets are fore-fronted and, (...) the source of much African epistemological self-consciousness." 22

While the question of the existence of African philosophy, of which African epistemology is part and parcel, has been settled by Mudimbe, Hountondji, Wiredu, Ramose and others. They believe that even though African epistemologies exist, the articulation of the nature of African epistemology still needs to be clarified. We may still need to find out if truly African epistemologies exist, then what would its nature look like. Secondly, we shall also need to investigate if and how this knowledge has been fractured, and if at all it can be reconstructed for the good of African development.

\section{Does African Epistemology Exist?}

To answer this question, I note that scholars are divided on the existence of African epistemology, as mentioned above. Airoboman and Asekhauno distinguish between the two camps; the traditionalists or protagonists and the modernists or antagonists. The protagonists argue that "there is African mode of knowing peculiar to Africans, context-dependent and social bound, and superior to other epistemologies". ${ }^{23}$ Some of the protagonists are Leopold Senghor, Anyanwu, Innocent Oyenwuenyi, Andrew Uduigwomen, Roy and Anselm Jimoh. ${ }^{24}$ The antagonists argue

“... the idea of peculiar African epistemology by its proponents is colourized with Western epistemological character [which] (...) make the discipline of African epistemology a mutt, too simplistic, commonplace, and bereft of epistemological nitty gritty". 25

Some of the antagonists are: Appiah, Bodunrin, Oruka and Wiredu to name a few. ${ }^{26}$

17

Dalene M. Swanson, "Ubuntu: An African contribution to (re)search for/with a 'humble togetherness"', Journal of Contemporary Issues in Education 54 (2007) 2, pp. 53-67, doi: https://doi.org/10.20355/c5pp4x.

18

Ibid., p. 54.

19

Ibid.

20

J. E. Ibuot, "Traditional African Ideology and the Challenges of Development in Nigeria", The Constitution 10 (2010), pp. 58-59.

21

Kwame Gyekye, An Essay on African Philosophical Thought: The Akan Conceptual Scheme, Tempels University Press, Philadelphia 1995, p. 46.
22

D. M. Swanson, "Ubuntu”, p. 54. 23

Cf. F. A. Airoboman, A. A. Asekhauno, "Is there an 'African' Epistemology?'.

24

Ibid., p. 15.

25

Ibid., p. 14.

26

Ibid. 
Udefi instead calls the antagonists Universalist or analytical African philosophers, who have "a passive acceptance or denial of the idea of African epistemology as propounded by its advocates". ${ }^{27} \mathrm{He}$ argues:

"Since the universalist group see philosophy as a rational and critical study of which argumentation and clarification are its essential hall marks, then it is only natural that they would reject as inadequate the idea of African epistemology since, as I stated above, that this epistemology depicts the way the African responds and interprets events in his cultural environment." 28

Those who accept the existence of African epistemology, take the idea of an African epistemology "as a way the African conceptualizes, interprets and apprehends reality within the context of African cultural or collective experience" ${ }^{29}$ Some of them are Jimoh and Thomas, who after acknowledging that epistemology, or any form of discipline at all, can be said to be the same all over, go on to say that we cannot deny the fact that there could be different approaches and perspectives by which we understand the world around us. ${ }^{30}$ They then went on to identify the nature of African epistemology as we shall see shortly.

Other authors that strongly believe, not only in the existence of African traditional knowledge but more specifically in the existence of African scientific knowledge are: David Millar, Stephen Bugu Kendie, Agnes Atia Apusigah, Bertus Haverkort, John R. S. Tabuti, etc. ${ }^{31}$ They had the following to say about African knowledge:

“African Traditional Knowledge (ATK), variously called rural peoples' knowledge, indigenous knowledge, or cultural knowledge, among others, is as old as the existence of the African peoples themselves. This knowledge base has provided sustenance for Africans in a diverse, complex, and risk-prone environment. Spirituality is the bedrock of this knowledge system that makes it remarkably different from other knowledge/sciences. Bio-cultural diversity is another feature that characterises African traditional knowledge." ${ }^{32}$

Tabuti, in the paper "Traditional Knowledge in Bulamogi County - Uganda: Importance for Sustainable Livelihoods", discovered from the results of his study that confirmed the widely held view that rural communities hold extensive traditional knowledge (TK) important for their survival, said the following:

“... community members held knowledge relevant for the exploitation of 315 plant species, to satisfy subsistence needs. In addition, the community was knowledgeable about the biology and ecology of the useful species. It was also found out that traditional spiritual beliefs were contributing to the conservation of plant species diversity." ${ }^{33}$

Furthermore, Millar posits that there is no one body of knowledge referred to as 'African Science' as you would for European or Western Science. It is more apt to refer to African Sciences because of the proliferation of expression of bodies of knowledge. He believes that the basic foundations of African epistemologies are similar; however differences accrue due to "the cultural, spiritual, philosophical and other specificities resulting from empirical encounters". ${ }^{34}$ Millar thinks that there is no distinction between 'science' and 'arts' in the African context.

"What rural people had was a body of knowledge constructed (and perpetually being reconstructed) from generation to generation and over time and space covering various livelihoods and life-encountered experiences." 35

In line with the above views, I strongly believe that African epistemologies exist and the basis for this assertion is the following. First of all, Africa has a long tradition of its history of existence and survival, which is impossible without some knowledge base. Secondly, this knowledge base is the reason 
for the construction of the habitat for her people, processing of her food needs, treatment of her ailments, to mention a few. If African epistemologies exist, then there must, like any other epistemologies, be attempts to explain its nature. There is no way all Africans would agree on a single explanatory theory with respect to the nature of knowledge. Given the fact that different parts of the world have different worldviews and philosophies, the nature of knowledge too can never be explained in the same or homogeneous way. However, even though this is the case, there are also greater similarities among the different African cultural communities. This creates the possibility that those with similar philosophical world views would have similarities in some of the aspects of these theoretical explanations. That is why, in this paper, I strongly believe that, given the fact that Africans share a lot more in common in terms of their worldviews and philosophies, there is a greater chance of having common grounds in trying to understand the nature of knowledge. The argument here is that there can be more similarities among Africans on the question of African epistemologies as is the case with African metaphysics. ${ }^{36}$

\section{The Nature of African Epistemologies}

To understand the basic features of African epistemologies, Anna Hunter begins by distinguishing traditional from indigenous knowledge. For Hunter, while traditional knowledge is knowledge developed over time in any society or culture; indigenous knowledge, which is a subset of traditional knowledge, is specifically knowledge grounded in an indigenous worldview. Hunter believes that indigenous knowledge is "a set of pre-suppositions, beliefs, and values system from which an individual interprets the world". 37

While the distinction between traditional and indigenous knowledge is acceptable, this paper is dealing with none of the two independently, but with

27

Amaechi Udefi, "The Rationale for an African Epistemology: A Critical Examination of the Igbo Views on Knowledge, Belief, and Justification", Canadian Social Science 10 (2014) 3, pp. 108-117, doi: https://doi. org/10.3968/4445.

28

Ibid., p. 113.

29

Ibid., p. 108.

30

Anselm Kole Jimoh, John Thomas, "An African Epistemological Approach to Epistemic Certitude and Scepticism", Research on $\mathrm{Hu}$ manity and Social Sciences 5 (2015) 11, pp. 54-61.

31

David Millar et al. (eds.), African knowledges and sciences: Understanding and supporting the ways of knowing in Sub-Saharan Africa, COMPAS/UDS/UCC, Barneveld 2006.

32

David Millar et al., "Introduction", in: D. Millar et al. (eds.), African knowledges and science, pp. 7-10, p. 8 .
33

John R. S. Tabuti, "Traditional knowledge in Bulamogi County - Uganda: Importance to sustainable livelihoods", in: D. Millar et al. (eds.), African knowledges and sciences, pp. 97-104, p. 98.

34

David Millar, "Ancestorcentrism: A basis for African Sciences and learning epistemologies", in: D. Millar et al. (eds.), African knowledges and sciences, pp. 53-63, p. 54.

35

Ibid.

36

Cf. Wilfred Lajul, “African Metaphysics. Traditional and Modern Discussions", in: Isaac E. Ukpokolo (ed.), Themes, Issues and Problems in African Philosophy, Palgrave Macmillan, Cham 2017, pp. 19-48.

37

Anna Hunter, Traditional and Western System of Knowledge, University of the Arctic 2007. 
African epistemologies in general, which encompasses both traditional and indigenous knowledge systems. My view is that African epistemologies are both traditional and indigenous because these knowledge systems are developed over time and grounded in African indigenous worldviews. Since I believe African epistemologies exist; it would be good to identify what constitute these epistemologies.

Some authors seem to accept that African epistemology is holistic, sociocultural, rational, justifiable, ontological, experiential, existential, unitary, hierarchical, temporal or local, relational, spiritual, theoretical and practical, resistant, and ethical. It may not be possible to discuss in details all these in a single chapter like this one, but I will deal only with the cultural and the ontological features of African epistemologies as discussed by Jimoh and Thomas since they take care of some of the features mentioned above.

Jimoh and Thomas believe that African philosophy is a cultural philosophy of integration where humans and nature exist concretely in a sacred unity. That they participate in the same locus without opposites. That African world is unitary as opposed to the Western world that is analytical and pluralistic. To support this, they wrote:

"The philosophy of integration and principles of understanding, as well as aesthetic continuum of the African cultural world, differ significantly from the Western world of ideas, especially when it comes to what constitutes trustworthy knowledge and reality. In classical African philosophy, there is a concrete existence of man and nature. African tradition only talks about two entities in terms of conceptual numerical and not in terms of separate ontological existence. It is impossible for the African to separate man from nature. They are sacredly united. In this unity they both participate in the same locus without being opposites. So, the African world is a unitary world as against the analytical and pluralistic world of Western thought." 38

First of all, in this text, there is a clear distinction on the concept of man and nature between Western philosophy and African philosophy, in the view of Jimoh and Thomas. They believe that African philosophy has the following features: man and nature exist concretely; the two entities cannot be separated; they are sacredly united; they participate in the same locus without opposites; and African world is unitary, while the Western world is analytical and pluralistic.

Secondly, Jimoh and Thomas distinguish traditional African epistemology from Western epistemology by methodology. Whereas Western epistemology emphasizes the scientific, rational and mathematical methodological paradigms, traditional African epistemology does not divide the domain of knowledge on the basis of such methodology. Instead, traditional African epistemology takes the rational, the empirical, and the mystical as constitutive of a single mode of knowing. To support this, they wrote:

"Since African ontology postulates a unitary world, traditional African epistemology does not attend to the problem of knowledge by dividing its domain into the rational, the empirical, and the mystical. The three constitute a single mode of knowing in both the intellectual and concrete divisions of reality. (...) Therefore, while Western scientific paradigm is laden with methodological and mathematical formulations, the traditional African paradigm goes beyond the outer reaches of formal logic. It goes beyond logic and acknowledges the irreducible mystery of the transcendent." 39

This implies that, since African world is unitary, so is traditional African epistemology, it does not divide its domain into the rational, the empirical, and the mystical because the three constitutes a single mode of knowing; Western scientific paradigm bases itself on methodological and mathematical formulations; traditional African paradigm goes beyond the methodological questions 
and acknowledges the irreducible mystery of the transcendental. Meaning, while Western epistemology insists on rationality, criticality, and logic as indispensable methodologies in deriving knowledge, traditional African epistemology goes beyond this limited methodology, to embrace the rational, the empirical and also the mystical, which is in the realm of the transcendental knowledge. Western epistemology tends to attribute this mystical dimension to the religious domain, which in their view, is not proper to philosophy. African epistemology insists that all three are part and parcel of the same reality and fall within the domain of knowledge.

Thirdly, Jimoh and Thomas distinguish Western from African epistemologies by the dualism between the subject (man) and the object (nature). Ruch and Anyanwu opine that "man and nature are not two separate independent and opposing realities but the one inseparable continuum of hierarchical order". ${ }^{40}$ Jimoh and Thomas write:

"Traditional African epistemology sees man and nature as one inseparable continuum. (...) While we may accuse Western philosophy of intellectual dogmatism that permits a dualism of the subject and object, and Asian philosophy of monism in attempting to deny the reality of the material, African philosophy tries to avoid the embarrassment of both concepts by seeking a central position for the ego (subject) in the cosmic scheme. In this way, subjectivism and objectivism do not constitute a problem to African epistemology. They are both subsumed in the unity of existence. In this unity; the subject gets to know the object. This will not be the case if they were detached." 41

Meaning that the traditional African epistemology has the following features: man and nature are seen as one inseparable continuum; African philosophy seeks the central position of the ego (subject) in the cosmic scheme; subjectivism and objectivism do not constitute a problem in African epistemology; both subjectivism and objectivism are subsumed in the unity of existence; and subject gets to know the object in this unitary existence. They think, Western epistemology's dogmatism permits a dualism of the subject and the object, while the Asian philosophy permits monism by denying the material world.

Lastly, Jimoh and Thomas say, African epistemology does not demarcate between epistemic subject and the epistemic object:

"The epistemic subject, which experiences the epistemic object and the epistemic object which is experienced are joined together such that the epistemic subject experiences the epistemic object in a sensuous, emotive, and intuitive understanding, as well as through abstraction, rather than through abstraction alone as it is the case in Western epistemology." 42

This means that African epistemology has the following features: it does not demarcate between epistemic subject and the epistemic object; epistemic subject experiences the epistemic object, and the two become joined together. The epistemic subject experiences the epistemic object in a sensuous, emotive and intuitive way, and as well as through abstraction. They distinguish

38

A. K. Jimoh, J. Thomas, “An African Epistemological Approach to Epistemic Certitude and Scepticism", p. 56.

39

Ibid.

40

Ernest A. Ruch, K. Chukwulozie Anyanwu, African Philosophy: An Introduction to the Main Philosophical Trends in Contemporary
Africa, Catholic Book Agency, Rome 1984, p. 146.

41

A. K. Jimoh, J. Thomas, "An African Epistemological Approach to Epistemic Certitude and Scepticism", p. 56.

42

Ibid 
this from Western epistemology, where the epistemic subject experiences the epistemic object through abstraction alone.

These are four central features of traditional African epistemologies as distinguished from Western epistemology. These features are derived from the nature of African philosophy itself as a philosophy of integration. From this philosophy of integration, traditional African epistemology is conceived as rational, empirical and mystical or transcendental. Thirdly, the dualistic relationship between the subject and the object, as is the case in Western epistemology, has been resolved in traditional African epistemology that sees the relationship between the subject and object as subsumed in the unity of existence. Lastly, the demarcation that exists between the epistemic subject that is to know the epistemic object through abstraction alone, and the traditional African epistemology, where the epistemic subject experiences the epistemic object in a sensuous, emotive, and intuitive way, without ignoring the abstraction.

Analysing these texts further, I would like to trace the point of similarity between traditional African epistemologies with any other epistemologies in the world. This is because, as Jimoh and Thomas observed:

“... we cannot continue to locate a discourse within a geographical boundary such as when we say African Epistemology or Western Epistemology. This is because the possibility of an unwarranted and unnecessary comparison is created. Such a comparison is bound to suffer an unprecedented casualty." 43

They also noticed that epistemology, like any other discipline, must have the same basis. However, different approaches to the same discipline should be expected because of the differences in the way we understand the world around us. They wrote:

"Epistemology, or any form of discipline at all, can be said to be the same all over. This notwithstanding, we cannot blankly deny the fact there could be different approaches and perspectives by which we understand the world around us. While we cannot argue that Africans have different cognition about the world from their Western counterpart as this may logically lead to conceptual relativity of some sort which ultimately may constitute an encumbrance to intelligibility; the fact remains that despite the uniformity of human nature, cultural and environmental nuances impose themselves on our understanding of reality. This fact is strongly reflected in Wiredu's thesis on Conceptual Decolonisation." 44

Then, the point of similarity between traditional African epistemologies and either Western or other epistemologies is that knowledge is the possession of the known by the knower. However, the interpretation of how these two aspects of the same realty relate and intimate with each other, depends on the philosophical orientation of a particular human community, whether in African or outside Africa.

In the forgone presentation and discussion, I have come to realize that, in traditional African epistemologies, the relationship between the subject and the object or, as Jimoh and Thomas called it, epistemic subject and epistemic object are intimately one. The epistemic subject does not just abstract knowledge from the epistemic object as is commonly insinuated in Western epistemology, but sensuously, emotively, intuitively, and rationally the two aspects of our knowledge become one. This makes knowledge to become a rational, empirical and mystical reality. I may not have a big problem with the views of Jimoh and Thomas that man and nature are sacredly united, but this does not mean their oneness prevents us to see their differences, since knowledge takes place inside the epistemic subject, while the epistemic object is internalized 
by the epistemic subject. This also means that there are similarities in most knowledge systems in the world, but one of the biggest differences between Western and traditional African epistemologies has been in the area of methodology, where the West insists; because epistemology is a philosophical subject, so it must employ the methodology used in general philosophy to derive its content; that is the use of reason and reason alone. African philosophy, together with different disciplines within it like epistemology, insists that such knowledge can and must employ all human faculties, like intuition, emotion and reason.

\section{Fractured African Epistemologies}

Over the years, knowledge process, in general, has progressed through three stages; the mastery of nature and its laws; the mastery of the applications of the laws of nature for technological advancements; and lastly, the mastery of manipulative skills of the laws of nature. (a) The first process is centred on the possession of the known by the knower. At this stage, knowledge was centrally the mastery of nature and its laws and how to benefit and live by those laws of nature. Through this knowledge, humans discovered the usefulness of several natural products in terms of their nutritional values as foods and medicinal benefits for improving human life and economic benefits derived from natural products. (b) The second is based on the possession of the derived laws of nature for technological advancement by the knower. At this second stage, knowledge was central, not just the mastery of nature and its laws, but the mastery of how to apply the laws of nature to derive technological skills and products useful for human survival and the improvement of the human living conditions and the quality of life. To do this, there were a lot of experimental adventures to explore and understand better these laws and how to use them for the good of man. (c) The third stage is based on the possession of the manipulative skills from those manipulated laws of nature by the knower. At this stage, knowledge is more than the application of the laws of nature, but manipulation of the laws of nature. From these, humans derived technical skills and products that had no semblance in nature; the genetic modifications, digital technologies, the GMOs, cloning, and a range of products, some of which can no longer be destroyed, but only re-cycled, such as plastics.

Africa came in contact with the West when most of its knowledge system was still at the first stage; when humans were still living by the laws of nature and the knowledge derived from nature itself. However, at the moment of this encounter, Africa had already gone beyond the mere possession of the known by the knower. They had gone to the second stage of applying the laws of nature for technological purposes and advancements. There were several instances, not only in ancient Egypt and Ethiopia but surprisingly even in the South African Cape Region, where there is evidence of the genesis of science in Africa. ${ }^{45}$

43

Ibid., p. 55.

44

A. K. Jimoh, J. Thomas, "An African Epistemological Approach to Epistemic Certitude and Scepticism", p. 55. Cf. Kwasi Wiredu, Conceptual Decolonization in African Philosophy: Four Essays, Hope Publications, Ibadan 1995.
45

Cf. Zenobia Jacobs et al., "Extending the chronology of deposits at Blombos Cave, South Africa, using optical dating of single and multiple grains of quartz", Journal of Human Evolution 51 (2006) 3, pp. 255-273, doi: https://doi.org/10.1016/j.jhevol.2006.03.007. 


\section{Emeagwali and Shizha point out:}

“... evidence found at Wonderwerk Cave in 2012, in South Africa, points to the earliest use of fire-making in the world, going back a million years. (...) The scientific world also discovered, with amazement, that ancient Africans developed the capacity to mix paint in containers in the form of abalone shells, and coat their ornaments with iron oxide pigment as early as 100,000 years ago, thus creating a world record, yet to be superseded in the annals of ancient science and technology. Assumptions and conjectures were made and so, too, long-term projections, in the assemblage of hammer-stones, grindstones, ochre, animal fat, iron oxide powder, and charcoal, to make the paint in the mini containers. These discoveries (...) have not only cast new light on the African genesis of chemistry but they have also confirmed the fact that Africa was indeed a birthplace of science as we know it, and that indigenous knowledge capabilities to cope with the environment and create value have a long history in the continent." 46

By giving this quotation, I am simply trying to show at what level of knowledge development had Africa reached at the time of her encounter with the Western knowledge system. It is not about what is Western and what is African. What is clear from the above text is that Africa had long tried to apply the laws of nature for their technological progress and advancement. This is not a discussion on the type of development Africa was following. Otherwise the mixture of ideas would create confusing about what I am trying to present. Thus, it is not about development trajectory premised on a Western conception of development or not, well aware of the intricacies about the use of the laws of nature to create technological advancements that improve the human condition without caring about their implications on the human environment.

\section{Emeagwali and Shizha concluded by saying:}

“... what is clear from these discoveries is that the knowledge evolving within the continent from this early period was aimed at problem-solving, and involved specific trial and error experimentation and goals." 47

With these instances, there is evidence that Africans had moved to the second stage of knowledge progression that was deriving from the laws of nature, the technological skills to produce what humans needed. Besides, evidence from the South African Cape mentioned above, evidence from Egypt and Ethiopia show technological knowledge for pot making, iron smelting, pyramid building, boat making, etc. Emeagwali and Shizha add that:

"By 9000 BC, some of the earliest ceramics emerged in Nubia, predating those of ancient Egypt and Ethiopia, which may have lagged behind in this sphere, relatively speaking, granted that Malian pots, dated 11,400 years ago, are older. By the Aksumite era of Ethiopian history, however, we have a wide range of ceramic products in the form of shallow thin-walled bowls, deep bowls with rims, basins, pots, jars, jugs, storage pots, braziers, legged vessels, beakers, semi-globular round-bottomed bowls, cooking pots, pedestal vessels and bird-shaped vessels, the product of indigenous innovation and skill. Fast-forward to the early and late Aksumite era, between $1000 \mathrm{BCE}$ and $1000 \mathrm{AD}$, and we have close to two hundred stelae obelisks, one of the largest being 33 metres (110 ft.) weighing 750 tons and representing a building, thirteen storeys high, the largest single block of stone ever quarried, sculptured and erected in the ancient world. Likewise, archaeologists have found in this region, evidence of numerous multi-storied residences, elite houses and mansions, some of which may have been palaces." 48

Though both Africa and Europe were more or less at the same levels of knowledge development processes, unfortunately, at the encounter with Western Europe, African knowledge progression was halted or fractured. In that, most Africans began to admire the technologies and knowledge system brought in by the West, abandoning their own. Most likely, at that stage, Western epistemology had mastered this second stage of knowledge process at a much higher level; they had already derived from the laws of nature technologies far supe- 
rior to those of the Africans, and this led to their conquest of the space, water, land and the air, and which greatly improved their lifestyles and eased their foreign conquests. They had already invented the gun, the steam engine, and other technologies by which they had become masters of the sea, of the air, and on land. African's natural process of knowledge acquisition was fractured at this moment. Africans, especially through Western education, started concentrating on acquiring and possessing derived knowledge, not from natural laws for technological advancement of their societies, but through borrowing from their colonisers, the Europeans. This meant that Africans started relying less and less on their traditional and indigenous knowledge systems to propel their evolving developments. This was the first stage of fracture in the African epistemological progression.

Complete fracture in African epistemology took place at the third stage of knowledge progression. The third stage of knowledge progression came when Western epistemologies introduced manipulative technologies. In this, it was no longer derivation of technologies from the laws of nature, but the derivation of technologies from the manipulation of the laws of nature. It all started with the theory of Kantian Copernican Revolution, ${ }^{49}$ when Kant proposed that man must stop obeying the laws of nature, and should rather begin subjecting the laws of nature to human reason, so that nature produces answers to solve human problems.

In talking about the role of practical reason, Immanuel Kant observed that there are three roles of practical reason: the first role of reason is to show the way, with principles of judgement, to nature's leading-strings, based upon fixed laws. Secondly, it is to discover necessary laws from well-thought-out plans. Thirdly, to constrain nature to answer questions of reason's own determining. ${ }^{50}$ Meaning, natural laws are just leading strings, indicative of where it aims to go. Practical human reason, after designing its laws, should show the way to this nature's leading strings. But using these well-thought-out rational laws, nature should then be constrained to give answers to the questions reason has pre-determined.

The implications of this theory are enormous in terms of human knowledge. From that moment, Western epistemology had reached the third stage of knowledge progression. African epistemologies became completely fractured coming in contact with this new knowledge system. Authors like Grosfoguel think it was not of their own accord that African epistemologies became "completely fractured". It was rather due to the contact with Western epis-

46

G. Emeagwali, E. Shizha, "Interconnecting History, African Indigenous Knowledge Systems and Science", p. 3. Francesco Berna et al., "Microstratigraphic evidence of in situ fire in the Acheulean strata of Wonderwerk Cave, Northern Cape province, South Africa", Proceedings of the National Academy of Science 109 (2012) 20, pp. E1215-E1220, doi: https:// doi.org/10.1073/pnas.1117620109; Christopher Stuart Henshilwood, "Fully symbolic sapiens behaviour. Innovation in the Middle Stone Age at Blombos Cave, South Africa", in: Paul Mellars et al. (eds.), Rethinking the human revolution: New behavioural and biological perspectives on the origins and dispersal of modern humans, University of Cambridge Press, Cambridge 2007, pp. 123-132.
47

G. Emeagwali, E. Shizha, "Interconnecting History, African Indigenous Knowledge Systems and Science", p. 4.

48

Ibid., p. 4.

49

Immanuel Kant, Critique of Pure Reason, translated by Norman K. Smith, Macmillan, London 1990, p. 22

50

Ibid., p. 20 . 
temic positions which stole from African knowledge systems and concealed the genesis of this knowledge. These ideas are reflected in "The Epistemic Decolonial Turn" 51 and "The Structure of Knowledge in the Westernized University". ${ }^{52}$ Falola and Heaton also believe that the work of undermining African epistemic positions was conducted on the political, economic and sociocultural front, through attempting to systematically erase African knowledge systems. This erasure was in some instances successful. ${ }^{53}$

In this paper, my view is to respect other people's views on this subject, but the focus is that, if there has been any attempt to erase African knowledge systems, it has been on the formal level. This is because at the informal level, Africans continued to survive and trace the meanings of their lives through the employment of their pristine knowledge systems. For instance, Africans continued to use their traditional and indigenous knowledge systems in their agricultural industries, maternal health and child-bearing practices, house construction technologies and nutritional food practices, and in the entertainment industry, to mention a few.

But at the formal level, from the time of Africa's encounter with Western knowledge system, Africans started to rely on foreign knowledge system for their survival and development; to meet their clothing, food production, digital and computer needs. Africans' struggle to improve the quality of their material and human needs is becoming dependent on Western knowledge system. For agricultural needs, for example, Africans now is to rely on genetically modified seeds (GMOs). For Africa to grow and take charge of her developmental needs, she needs to reconstruct a type of knowledge systems that can propel their development.

\section{Proposals for Reconstructing the Fractured African Epistemologies}

While Kant thought that manipulative technologies were possible through the power of the human mind, Nietzsche saw them as a result of the knowledge of physics. It is this manipulative ability of the physical world by the power of the human mind that characterises Western epistemology and distinguishes it from African epistemology. It also makes the epistemological process purely the business of human reason, totally ignoring the involvement of other equally important faculties in the process of deriving knowledge. If there is anything that distinguishes African epistemology from modern Western epistemology, then this is centrally the issue that Africa epistemologies is not solely a rational enterprise, but it is the process of deriving knowledge through the involvement of all human faculties, like reason, feeling, intuition, faith and emotions. To reconstruct the fractured African epistemologies, Africans should realize that manipulative technologies, with all its assumed benefits, are founded on a wrong epistemological premise. This premise is based on the wrong methodology for knowledge acquisition; that is an over rationalisation of the knowledge process.

By over rationalisation I mean, the over-reliance on human rationality without balancing it with other equally important faculties of man in the process of deriving knowledge. Just read what Kant himself, the originator of this over rationalisation, said:

"The practical rule, which is here a law, absolutely and directly determines the will objectively, for pure reason, the practical in itself, is here directly law-giving." ${ }^{\prime 4}$ 
Meaning, human reason is directly a law-giving faculty, the determinant of the objective will, the pure reason, which is practical in itself. Commenting on Kant's Copernican Revolution, McCormick wrote:

"Kant argued that we must reformulate the way we think about our relationship to objects. It is the mind itself which gives objects at least some of their characteristics because they conform to its structure and conceptual capacities. The mind thus plays an active role in helping to create a world that is experiential and we must put it at the centre of our philosophical investigation." 55

Previously I made a comment on this matter:

Man has been raised beyond nature by his supersensible faculty of freedom. This supersensible faculty is based on rational principle of reason and its nature is autonomous. In this sense, reason makes man an end in himself and the final purpose. He is raised beyond nature because of his rational capacity. This faculty of freedom makes man autonomous and a law of causality. ${ }^{56} \mathrm{Im}$ plying, human reason raises humans beyond nature. This law-giving faculty makes humans become ends in themselves and the final purpose of life. This faculty of human freedom makes humans autonomous and law of causality. I would add, reason becomes the only basis for determining objective knowledge. Thus, when Kant said that practical reason should show the way for nature's leading strings; that man must use his own designed rational laws, and man should constrain nature to produce answers for questions designed by reason alone, ${ }^{57}$ we were pushed to the maximum limits of rationalism in human history.

In effect, while earlier versions of rationalism had insinuated that truth is only arrived at by the use of human reason, Kantian Copernican Revolution theory pushed this rational theory of knowledge to the limit. One shouldn't doubt the fact that this singular invention of Kant has pushed human technologies to the level it has reached. Humans can now talk of the digital technologies, engineering technologies and modification of genes, giving rise to a range of modern products without any semblance in nature. However, the side effects of some of these technologies will soon get rid of organic foods, crops and their seeds, and when this is done there will be no coming back to reproduce organic foods in human life. Humans and their environment will be affected as concomitant results of this invention in a way that will not be easy to reverse.

51

R. Grosfoguel, "The Epistemic Decolonial Turn", p. 212.

52

Cf. Ramón Grosfoguel, "The structure of knowledge in westernized universities: Epistemic racism/sexism and the four genocides of the long 16th century", Human Architecture: Journal of the Sociology of Self-Knowledge 11 (2013) 1, pp. 73-90.

53

Cf. Toyin Falola, Matthew M. Heaton, A History of Nigeria, Cambridge University Press, Cambridge 2008, doi: https://doi.org/10.1017/ cbo9780511819711.

54

Immanuel Kant, Critique of Practical Reason, translated by Thomas White Beck, Macmillan Publishing Company, New York 1993, p. 31.
55

Matt McCormick, 'Kant's Copernican Revolution: Mind Making Nature', in: "Immanuel Kant: Metaphysics", Internet Encyclopedia of Philosophy. Available at: https://www.iep. utm.edu/kantmeta/\#H3 (accessed on April 10, 2018).

56

As written in: Wilfred Lajul, The Role of Man in the Dynamics of History: Reflections on Kant, Urban University Press, Rome 1994, p. 90 .

57

I. Kant, Critique of Pure Reason, p. 65. 
This view is supported by Pope Francis, when he wrote in his Encyclical Letter Laudato $S i,{ }^{58}$ that he agrees with his predecessor, Pope Benedict XVI who said that "technology itself expresses the inner tension that impels man gradually to overcome material limitations", ${ }^{59}$ but he regrets that

“... there is a tendency to believe that every increase in power means 'an increase of 'progress' itself' an advance in 'security, usefulness, welfare and vigour; (...) an assimilation of new values into the stream of culture', as if reality, goodness and truth automatically flow from technological and economic power as such." 60

He concluded by saying:

"The technocratic paradigm also tends to dominate economic and political life. The economy accepts every advance in technology with a view to profit, without concern for its potentially negative impact on human beings." 61

With these heavy sentiments, we want still to discuss how these fractured African epistemologies can be reconstructed. To reconstruct these fractured African epistemologies, the following will have to be done. First, we have seen that the real issues surrounding knowledge is to define the relationship between the subject that knows and the object that is known. Earlier, we have seen that during the first phase of knowledge progression, humans tried to master nature and its laws. During the second stage of knowledge progression, it is the possession of the derived laws of nature for technological advancement. At the third stage, true knowledge is now the possession of the manipulative skills from the manipulated laws of nature by the knower. The Kantian Copernican Revolution is central to understanding this third stage of knowledge progression. All these stages talk about the relationship between the knower and the known.

For African fractured epistemologies or halted progression in knowledge generation and acquisition, Africans must first continue to experiment and discover useful technological models that can help to improve man's lot without jeopardising the environment within which humans live. Western knowledge system has done this without taking care of the environment. Today, the West is trying to reverse this trend with a lot of difficulties, when they advocate environmental concerns in building new technologies. This mistake should not be repeated in any attempt to reconstruct fractured African epistemologies. This is in line with efforts and attempts by humans to express the inner tension that impels them to gradually overcome material limitations, as indicated by Pope Benedict XVI above.

Secondly, instead of manipulating the laws of nature to find solutions to human problems, humans should design laws that can invigorate, vivify and animate the objective world to make it more productive and profitable for human survival and development. Thirdly, humans should use all the available and valuable resources and capacities with which they have been endowed; the rational, emotional, intuitive, and experiential, to enrich their knowledge base for the good of African development.

In this chapter I understand development as the ability to make ever better the conditions of living for all in society; economically and humanly. It is improving the factors that make better the conditions of living of humans, who are the agents of development. True development, in this sense, is both an economic progress and people-centred. The key elements of such development are promoting human capacity for qualitative change, ability to protect the environment, and the capacity of human progress by human knowledge, and proper utilization of the available human and natural resources. 
To achieve this type of development, Africans should not only use their rationalities, but also all their faculties, like emotions, intuition, faith and of cause reason, to design and build economic and technological systems that are useful for humans and their environment. For instance, instead of promoting nuclear energies, which is a result of the manipulation of atoms in minerals for their industrial development, Africans could use other available sources of energy, like solar energies and hydroelectric powers.

Fourthly, in line with Jimoh and Thomas, I would propose that to reconstruct African epistemologies, respect must be given to these two dimensions of human knowledge; the knowing subject and the known object, without patronizing the subject and its rationality at the expense of the known object, the material world being manipulated. This is what is contained in Jimoh and Thomas words:

"The self of the subject and the objective world outside the self are united as one in a relationship in which the self of the subject vivifies and animates the objective world." 62

This means the subject should invigorate, vivify and animate the objective world that is known. As we have seen above, the modern Western knowledge system that relies on Kant's Copernican Revolution theory is tasking the subject of knowledge to manipulate the objective world and its laws. This creates a dualistic dichotomy between the subject of knowledge and its object, resulting in the degradation of the objective world or the environment, as we are beginning to see in the world today. In reconstructing their epistemologies, African epistemologists should create harmony between the subject of knowledge and the objective world that is known, by invigorating, vivifying and animating it to become more productive and useful for humanity. This is to ensure, as Pope Francis said, the intrinsic dignity of the world is not compromised. ${ }^{63}$

Just like Kant, Friedrich Nietzsche thought that humans could create themselves by the laws that they themselves had created from physics. He wrote:

"We, however, want to become those we are-human beings who are new, unique, incomparable, who give themselves laws, who create themselves. To that end we must become the best learners and discoverers of everything that is lawful and necessary in the world: we must become physicists to be able to be creators in this sense." ${ }^{64}$

To reconstruct African fractured epistemology, we need not only to resist this new epistemological paradigm, where humans become the creators of themselves and their world but also design new and better epistemological paradigms that suit and respects the intrinsic dignity of the world and the ethical value of knowledge, for the good of humanity. I subsequently agree

58

Pope Francis, Encyclical Letter, 'Laudato Si' of the Holy Father Francis on Care For our Common Home, Vatican Press, Rome 2015.

59

Benedict XVI, Encyclical Letter Caritas in Veritate (June 29, 2009), 69: AAS 101 (2009), 702.

60

Pope Francis, 'Laudato Si', §105, pp. 7778).

61

Ibid., $\$ 109$
62

A. K. Jimoh, J. Thomas, "An African Epistemological Approach to Epistemic Certitude and Scepticism”, p. 57.

63

Pope Francis, 'Laudato Si', §115, p. 86.

64

Friedrich Nietzsche, Gay Science, translated by Walter Kaufmann, Random House, New York 1974, p. 266 
with Anyanwu, when he says that "the co-operation of all human faculties and experiences (as a man) sees, feels, imagines, reasons, or thinks and intuits all at the same time", ${ }^{65}$ are important in the process of deriving knowledge. That is also what Nasseem said, "the cognitive process is not complete without the experiential". ${ }^{66}$ Therefore, in the reconstruction of African epistemologies, we should accept that the cognitive process of knowledge is not complete until all the rational, experiential, and the intuitive dimensions of knowledge are involved.

Writing on the ontology of African philosophy, Ekanem questions if

“... this metaphysical and spiritual posture of African philosophy have any substance which can be practical and useful to us in solving our existential challenges? [Then he clarifies that] this metaphysical and spiritual under-pinning of African philosophy is more of co-existence with nature, rather than conquest, more of collectivism, rather than individualism, more of holism, rather than atomism, more of synthesis, rather than analysis." 67

However, my view represents a moderate communitarianism as it is advocated by Kwame Gyekye. This is because a human person, in African ontology, is both communitarian and individualistic. They are corporate social individuals. Meaning, an individual needs society, but also has individuality of one's being. Implying, human knowledge is also basically an individual affair, but knowledge that has been generated by an individual can be communally owned and used, depending on its usefulness and relevance to society.

Apparently, Ekanem answers his own question by saying, if the metaphysical and spiritual posture of African philosophy, or in our case epistemology, is to be reconstructed, then we must make African epistemology create a relationship of co-existence between the subject that knows (man) and the objective world that is known; other than in making the subject that knows (man) to seek ways of conquering the objective world (as Kant proposed). The subjects of knowledge should care for the collective welfare of all, including the natural integrity of the objective world, other than working only for individualistic interests, like solving the problems of humans alone. This does not make the subject that knows have the same nature as the object that is known. It only means that, in the process of knowing, both the subject that knows and the object that is known is equally important, since, without any of the two, knowledge cannot take place.

Bakari on the other hand, talks of Afrocentric epistemologies, as

“... the African ancestors' ways of knowing and understanding filtered through the chaos of slavery and oppression and [which] became embedded in the spirits, hearts, and souls of their descendants." 68

Meaning, the lessons Africans are learning through their eventful histories should become the knowledge base for their continued struggle for ever better conditions of living for all in society; economically and humanly. As Africans engage with the realities of poverty, under-development, famine, politicoeconomic instability, they should learn to derive lessons with which they can overcome the same maladies.

Seth emphasizes that indigenous knowledge that is useful for development is one that can solve problems. Thus, African epistemologies should leverage human welfare and development; should solve social problems; it is essential for empowerment in a people-centred development; in dealing with environmental problems; in reducing chances of deskilling and dependency on external experts. ${ }^{69}$ 


\section{African Knowledge-Based Development}

In this section, I will investigate the meaning of knowledge-based development, and show how the possibly reconstructed African epistemologies can be used to promote such development.

\section{Knowledge-Based Development}

Carrillo defines knowledge-based development (KBD), as "a new cultural, political and economic order giving as much priority to intangible value or intellectual assets as it has so far done to the material and monetary".$^{70}$ This means, in the resource-based development (RBD) paradigm, priority was given to the material and monetary assets to propel cultural, political and economic development. Instead in KBD, priority is now to be given to the intangible value or the intellectual assets in propelling cultural, political and economic development.

Carrillo clarifies the concept KBD as the knowledge-intensive transactions that improve the human capacity for cultural evolution, human civilisation, balanced production, consumption, distribution; and improving the capacity to identify, agree, implement and evaluate sets of common values for ethics, politics, economics and culture. ${ }^{71}$ For him, the aims of KBD are; the correction of major environmental, social, and gender unbalances; the dynamic identification, measurement and balance of all value elements shared by developing communities; and multiplying the overlap between knowledge and locus of growth (the city), knowledge and economy, knowledge and society, and going beyond the boundaries of resource-based economic development paradigm. ${ }^{72}$ What is central in KBD, according to Carrillo, are the three necessary conditions for knowledge events:

65

E. A. Ruch, K. C. Anyanwu, African Philosophy, p. 146.

66

Zubairi 'b. Nasseem, "African Heritage and Contemporary Life: An Experience of Epistemological Change", in: Albert Titus Dalfovo et al. (eds.), The Foundations of Social Life. Ugandan Philosophical Studies, I, The Council for Research in Values and Philosophy, Washington D. C. 1992, pp. 13-28, p. 19.

67

Cf. Ekanem E. Francis, "On the Ontology of African Philosophy", International Journal of Humanities and Social Science Invention 1 (2012) 1, pp. 54-58; Campbell S. Momoh (ed.), The Substance of African Philosophy, African Philosophy Projects Publications, Auchi 1989, p. 59.

68

R. Sentwali Bakari, "Epistemology from an Afrocentric Perspective. Enhancing Black Students' Consciousness through an Afrocentric Way of Knowing", Different Perspectives on Majority Rules 1997. Available at: http:// digitalcommons.unl.edu/pocpwi2/20/ (accessed on April 10, 2018).
69

Cf. Seth Oppong, "Indigenizing Knowledge for Development. Epistemological and Pedagogical Approaches", Africanus 43 (2013) 2, pp.34-50, doi: https://doi.org/10.25159/0304$615 \mathrm{x} / 2300$.

70

Cf. Javier Carrillo, "Knowledge-based development as a new economic culture", Journal of Open Innovation. Technology, Market, and Complexity 3 (2015) 1, pp. 1-17, https://doi. org/10.1186/s40852-015-0017-5.

71

Ibid., p. 4. Cf. Stephen Gudeman, Economics as Culture. Models and Metaphors of Livelihood, Routledge, London 1986.

72

J. Carrillo, "Knowledge-based development as a new economic culture", p. 4. 
"These are: first, knowledge object: that which is known. Secondly, knowledge agent: he/she who knows. Third and critically, knowledge context: the axiological and semiotic references that provide value and meaning and therefore, economic and cultural significance."73

As I have mentioned earlier, knowledge is the relationship between the object and the agent that knows. The emphasis in the KBD is on the second and third knowledge events mentioned by Carrillo; the knowledge agent and the knowledge context. While the context provides the values and meanings about economic and cultural significance, the agent would provide the base for any meaningful development. It is the agent who would derive the economic values, meanings and cultural significance for development, not just the object in terms of natural resources. This means that, though the context is important for both resource-based development (RBD) and KBD, the former emphasizes the importance of the object; that needs to be exploited and value added to it to propel development. In KBD, however, the emphasis lies with the agent, who exploits and adds value to the objects as components of any meaningful development.

Carrillo observes that there are three generations of KBD. The first generation is object cntred and focuses on object attributes, the second generation is agent centred and focuses on agent attributes, and the third generation focuses on the context attributes, which is meaning and value. The object attributes alluded to here are; "medium nature (caved stone, manuscript, printed paper, magnetic recording, digital screen, augmented reality display) and content molarity (data, information, knowledge)" ${ }^{74}$ The object attributes seem to refer to the tools of production, like the technologies and the material world to be transformed into useful products.

The agent attributes referred to here are; "structure (roles and hierarchy) as well as relevant agent competencies (code or language proficiency, procedural knowhow)". ${ }^{75}$ This refers to the human resources, with their skills, capacities, ingenuity, management skills, proficiencies and technical knowhow. The third KBD generation, focusing on meaning and value, brings to the forefront "the received distinction between tangible or traditional capital (physical + monetary) and intangible value or intellectual capital". ${ }^{76}$

At this third level, meaning and value that distinguishes RBD from KBD are identified by Carrillo as follows. RBD, which is based on traditional capital is: tangible, physical, monetary, resource- intensive, segregative and selective. On the other hand, KBD, which is based on intellective capital are: intangible, value centred, significant, knowledge-intensive, integrative and all-inclusive. ${ }^{77}$ Thus, for KBD to take place, we should now begin from the agent of development other than from the object of development. However, this agent should use his or her knowledge to derive values and meanings which are used to direct development by producing, the tangible, the physical, the monetary, the economic, the socio-political and the cultural products needed for propelling people-centred, ethical, integrative, and inclusive human development.

\section{Knowledge-Based African Development}

Chukwuokolo defines development as "holistic evolution of all the aspects of the society, namely politically, socially, psychologically, religiously, intellectually, technologically, scientifically and culturally for the advancement of the society as a whole as an aggregate of individuals". ${ }^{78}$ Agbakoba has also defined development as "a process by which humans seek to maximise the 
realisation of themselves" ${ }^{79}$ Mabogunje thinks that development is "essentially a human issue, a concern with the capacity of individuals, to realise their inherent potentials and effectively to cope with the changing circumstances of their lives". 80

In these quotations, I can see that development is described as holistic evolution, attempts of humans to maximise their self-realization, or individual's ability to realise their inherent potentials to cope with the changing circumstances of their lives. We have earlier defined development as qualitative changes in both the human and the economic conditions of human life. The description given here emphasises the qualitative changes in the human condition of life other than the economic condition which, as we have already noticed, is also important for any qualitative change in the human condition of life.

Agbakoba clarifies that the notion of self-realization delineates development as universal and particular. The universal dimensions of self-realisation consist of those values, orientations, attitudes, ideas, practices and objects which are necessary, either as preconditions or as enhancing conditions, for the realisation of people across the globe while particular aspects of development are those that concern specific communities and individuals. These definitions delineate that development is not just a matter of economic growth, which has been the wrong parameters by which African development has been measured, showing Africa as under-developed and the third world.

Such a development concept was not only responsible for the wrong effort put in imitating Western models of development, but it has also prevented Africa from developing an Afrocentric development model. This was compounded by the interest of the West in the resources that were abundantly available in Africa. A number of African development partners, of the economic development dispensation, championed by the Free market economy, propagate that if Africa would industrialize, meaning import industrial machinery together with the technological skills from Europe, Africa would automatically take a great leap from under-development to a middle-income economy and finally to the first world economy. This was carried out under the disguise that, this could happen only when Africa opens its markets to the West; where the industrial products produced in Africa would be sold, also that African products would freely compete with the industrial products produced from the developed worlds.

What it turned out to be was that developed countries would never export the knowledge skills behind the industrial technology they would export. Africa

73

Ibid., p. 3. Cf. Javier F. Carrillo, "Managing Knowledge-based Value Systems", Journal of Knowledge Management 1 (1997) 4, pp. 280-286.

74

J. Carrillo, "Knowledge-based development as a new economic culture", p. 3.

75

Ibid.

76

Ibid.

77

Ibid.
78

J. Chidozie Chukwuokolo, "Afrocentrism or Eurocentrism: The Dilemma Of African Development", Ogirisi: A New Journal of African Studies 6 (2009) 1, pp. 24-39, p. 28.

79

Joseph C. A. Agbakoba, A Critical Examination of the Concept of Development and Development Philosophy in Relation to Africa, Unpublished, Nsukka 2005, p. 2.

80

Akin Mabogunje, The Development Process. A Spatial Perspective, Hudtchinson \& Co., London 1980, p. 45. 
then became the locus to solve European unemployment problems. Europeans did not only export their industrial technology to Africa, but they also exported technical experts to Africa. Besides, most of them sold the outdated technologies to Africa, to give space for their newly improved industrial technologies. Africa became the dumping ground for the obsolete European industrial technologies, placed on the African continent without the technical skills to run them; and where there were technical skills, that were imported from the West.

I am aware that African political economy, which sees much of the development in Africa, is arrested by wars, failing democratic institutions, military dictatorships on the continent and the reality that Western powers continue to benefit from this instability on the continent. However, this may be a topic for another day; here the concern is about African development and its knowledge base. As much as the above factors create African under-development, the focus here is to look at this phenomenon as a result of Africans inability to make use of their home-grown knowledge systems to manage their economic and human developments. African's human resources are underutilised, poorly prepared, and if prepared, they are prepared by the Western knowledge system. But more seriously, there is no clearly defined or established African knowledge systems on which their development could ever be propelled since the African knowledge systems were halted when Africa came in contact with the West.

The solution to this is for Africa to build its industrial capacities and the technical skills that come with the industrial technologies designed and managed by Africans themselves. This is centrally, what is behind the knowledge-based development. The Asian countries have developed because of the KBD development skills they had acquired and built for themselves over the years. Africa may continue to have an abundance of natural resources, but without the technical skills and right technologies to process them, African wealth will continue to be expatriated to the countries from which those industrial technologies and technical skills come. A country cannot develop by borrowed technical skills and knowledge. Africa has to reconstruct its knowledge base. This is the idea behind Afrocentric development.

Onyewuenyi contends that Afrocentrism, means African centeredness, and it is a resolute attempt to place African people within their historical framework. It is a demand that the contributions of Africans in all areas of civilisation be reflected in world history. ${ }^{81}$ Unlike Onyewuenyi, our interest here is to place Africans at the centre of their development. Though we agree with Onyewuenyi that, education is the answer to this quagmire, however, it is not the Western type of education African has received up to now; we need an Afrocentric educational system, as a propellant of African knowledge-based development.

\section{Conclusion}

In this paper, I have discussed the paradoxical development situation of Africa, as a continent with plenty of natural resources, but with least development. As the world moves away from an RBD to KBD, Africa is left behind, not because she did not have knowledge systems that are originated on its continent, but because its indigenous knowledge systems were disrupted with the coming of Western colonisation. The critical issue is how to reverse this trend, and put Africa back on the track of development. 
In this paper, I have tried to identify the basic features of this fracture in African knowledge systems and became convinced that it was centrally in stagnating the already progressing knowledge base of Africa and replacing it with the Western knowledge system, that did more damage than good. So much resource has been put into African development programs, but the result has not been worthwhile. The reason is that no continent can develop by borrowed knowledge, technologies and the technical skills behind them. Africa is then to reconstruct its fractured epistemologies from the broken pieces and try to build new knowledge systems. Its worst effect will be felt in the destruction of the organic and natural environment in the human world.

Africa will for sure continue to learn from nature, experiment with nature and continue to produce products needed for human survival and development, without jeopardising human life and integrity of the natural world. Africa will have to desist from over patronising rationality at the expense of other faculties and capacities with which human beings have been endowed. These capacities will be useful in the building of the sound African knowledge base that will be used as the basis of her development. Lastly, man will continue to balance the importance of the subject that knows and the object that is known, without making the knower becoming more important and destructive to the very objective world it tries to know and utilize; the objective world with which man should continue to use and live in harmony for the good of his present and future generations.

\title{
Wilfred Lajul \\ $\underline{\text { Rekonstruiranje afričkih razlomljenih }}$ epistemologija za afrički razvoj
}

\begin{abstract}
Sažetak
Afrika je kontinent s pregršt prirodnih izvora, ali je ekonomski siromašan. Da bi se prirodni izvori preveli u profitabilno obilje kakvo pospješuje kvalitetu života i dobrobit ljudi, potrebno je znanje. Iako se ne može poreći da je Afrika, mnogo prije kontakta sa Zapadom, imala svoje sustave domorodačkog znanja, svejedno se pitamo što je pošlo po zlu. Čini se da srž problema leži u raskidu s nasljedstvom domorodačkog znanja. Razlog je to što se Afrika, dok današnji svijet prelazi s razvoja zasnovanog na resursima na razvoj temeljen na znanju, sa svojim razlomljenim epistemologijama, oslanja na bogate prirodne izvore kojima se, nažalost, loše upravlja zbog slabe obrazovne osnove. Da bi se pomak dogodio, Afrika mora obnoviti svoje razlomljene sustave znanja. Rad postavlja hipotezu da je navedeno moguće jedino kroz istraživanje prirode afričkih razlomljenih epistemologija da bi se razumjelo što je pošlo krivo i kako stvari ispravno postaviti da bi se obnovio afrički razvoj.
\end{abstract}

Ključne riječi

Afrika, razlomljena epistemologija, rekonstrukcija, razvoj, priroda 


\title{
Wilfred Lajul \\ Rekonstruierung afrikanischer zerbrochener Epistemologien für die Entwicklung Afrikas
}

\begin{abstract}
Zusammenfassung
Afrika ist ein Kontinent mit einer Vielzahl von natürlichen Ressourcen, jedoch wirtschaftlich arm. Um die natürlichen Ressourcen in einen gewinnbringenden Überfluss zu überführen, der die Lebensqualität und das Gemeinwohl der Menschen begünstigt, ist Wissen erforderlich. Obgleich nicht zu leugnen ist, dass Afrika lange vor dem Kontakt mit dem Westen über eigene indigene Wissenssysteme verfügte, fragen wir uns nichtsdestotrotz, was genau fehlschlug. Der Kern des Problems scheint im Bruch mit der Vererbung des indigenen Wissens zu liegen. Der Grund dafür ist, dass während die gegenwärtige Welt von der ressourcenbasierten zu einer wissensfundierten Entwicklung übergeht, ist Afrika mit seinen zerbrochenen Epistemologien auf die reichen natürlichen Ressourcen angewiesen, die leider aufgrund einer schwachen Bildungsbasis mangelhaft verwaltet werden. Um diesen Durchbruch zu vollziehen, muss Afrika seine zerbrochenen Wissenssysteme erneuern. In dem Beitrag wird die Hypothese aufgestellt, das Erwähnte sei ausschließlich durch die Erforschung der Natur afrikanischer zerbrochener Epistemologien ausführbar, um zu begreifen, was misslungen ist und wie man die Dinge richtig aufstellen muss, um der afrikanischen Entwicklung neue Anstöße zu geben.
\end{abstract}

\section{Schlüsselwörter}

Afrika, zerbrochene Epistemologie, Rekonstruktion, Entwicklung, Natur

\section{Wilfred Lajul \\ Reconstruire l'épistémologie africaine morcelée pour un développement en Afrique}

\begin{abstract}
Résumé
L'Afrique est un continent riche en ressources naturelles, mais pauvre d'un point de vue économique. Afin que les ressources naturelles se transforment en richesses rentables qui améliorent la qualité de vie et le bien-être des gens, la connaissance est indispensable. Même s'il n'est pas possible de nier que l'Afrique, bien avant qu'elle n'entre en contact avec l'Occident, ait eu des systèmes indigènes de connaissances, il est tout de même légitime de se demander ce qui a mal tourné. Il semble que le coeur du problème se situe dans la rupture avec l'héritage du savoir indigène. La raison en est que, alors que le monde actuel est passé d'un progrès basé sur les ressources à un progrès fondé sur la connaissance, l'Afrique, avec ses épistémologies morcelées, s'appuie sur ses riches ressources naturelles qui sont malheureusement mal gérées dî aux faibles bases éducatives. Pour qu'un changement se produise, l'Afrique doit renouveler ses systèmes de connaissances morcelées. Ce travail avance l'hypothèse selon laquelle le susdit est possible uniquement par le biais d'une recherche sur la nature des épistémologies africaines morcelées afin de comprendre ce qui a mal tourné et d'établir les choses justement dans le but de renouveler le développement en Afrique.
\end{abstract}

\section{Mots-clés}

Afrique, épistémologie morcelée, reconstruction, développement, nature 